\title{
Karakter dan Potensi Risiko Kerusakan Ekosistem Karst Cekungan Air Tanah Watuputih Kabupaten Rembang, Provinsi Jawa Tengah
}

\author{
Nandra Eko Nugroho dan Eko Teguh Paripurno \\ Jurusan Teknik Lingkungan, Fakultas Teknologi Mineral, UPN "Veteran" Yogyakarta \\ Jl. SWK 104 Condong Catur, Depok, Sleman, Yogyakarta \\ E-mail korespondensi: nandranugroho@upnyk.ac.id
}

\begin{abstract}
ABSTRAK
Daerah telitian merupakan kawasan kars yang sedang berkembang bagian dari Kawasan Kars Kendeng di Kabupaten Rembang, dimana proses karstifikasi terus berjalan serta memiliki sistem bawah permukaan yang komplek. Selain kawasan karst Cekungan Air Tanah (CAT) Watuputih yang tertuang dalam Keputusan Presiden Nomor 26 Tahun 2011 poin 124 masuk dalam klasifikasi CAT B yaitu berada di lintas kabupaten antara Kabupaten Rembang dan Blora. Perubahan morfologi yang disebebkan ulah manusia maupaun berbagi kegiatan penambngan dan rencana pembangunan pabrik semen oleh PT SI dan anak perusahaanya seperti PT SG juga infestor seperti PT SIR, PT RSI, PT GMM, PT BA, PT RBP, PT SAF, PT ICCI yang mencapai luasan 493 hektare di Tegaldowo, Kecamatan Gunem. Kegiatan-kegiatan tersebut secara langsung maupun tidak langsung akan merusak ekosistem gua, sungai bawah tanah dan mata air parenial yang tersebar di wilayah CAT Watuputih. Sungai Bengawan Solo, Sungai Lusi dan Sungai Tuyuhan merupakan sungai besar yang berhulu di wilayah CAT Watuputih. Terdapat 74 gua, 29 mata air, 44 ponor yang berada di daerah Tegaldowo dan Timbrangan, 10 gua dan 3 mata air diantaranya berada di kawasan Perhutani. Perubahan morfologi akibat penambangan dapat mempengaruhi pola distribusi air, dimana gua, mata air dan ponor memiliki peran sangat penting yang mengontrol suplai air, degradasi jumlah air yang tersimpan di dalam CAT Watuputih mengakibatkan perubahan komposisi aliran dasar (diffuse flow) dibanding aliran total. Penambangan bukit gamping akan mengurangi fungsi resapan dan jumlah simpanan air diffuse, sebaliknya akan meningkatkan aliran conduit saat hujan. Apabila sebuah kawasan memiliki kriteria sebagai kawasan karst dan CAT maka harus menjadi perhatian utama dalam keberlanjutan ekosistemnya. Memberikan perlindungan dan menghentikan semua aktifitas yang dapat merusak kawasan lindung geologi yang memiliki bentang alam karst dan imbuhan air, terutama dari kegiatan tambang sekala kecil maupun secara masif. Memberi pemahaman tentang kawasan karst dalam perspektif pengurangan risiko bencana. Perlu dikembangkan dan diinformasikan ke berbagai pihak lintas sektor dan lintas administrasi sehingga dapat dilakukan kebijakan yang tepat sebagai fungsi ekologis.
\end{abstract}

Kata Kunci : CAT Watuputih, Distribusi Air, Ekosistemnya, Fungsi Ekologis, Perlindungan

\begin{abstract}
ABSTRCT
The research area is a burgeoning karst area which is part of the Kendeng Kars area in Rembang Regency, where the karstification process continues and has a complex subsurface system. In addition to the karst area of the Watuputih Groundwater Basin (CAT) written in Presidential Decree Number 26 of 2011 point 124 is included in the CAT B classification, which is located across the regency between Rembang and Blora Regencies. The morphological changes caused by human beings and the sharing of mining activities and plans for the construction of a cement factory by PT SI and its subsidiaries such as PT SG are also investors such as PT SIR, PT RSI, PT GMM, PT BA, PT RBP, PT SAF, PT ICCI which have reached an area 493 hectares in Tegaldowo, Gunem District. These activities will directly or indirectly damage the ecosystem of caves, underground rivers and parental springs that are scattered in the Watuputih CAT area. The Bengawan Solo River, the Lusi River and the Tuyuhan River are large rivers that tipped in the Watuputih CAT area. There are 74 caves, 29 springs, 44 ponors in the Tegaldowo
\end{abstract}




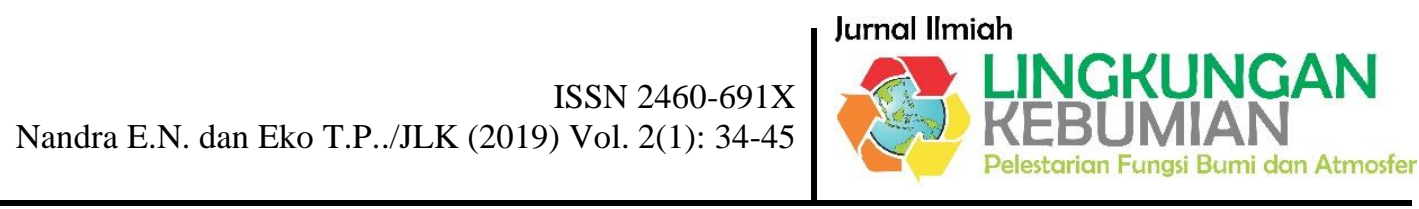

and Timbrangan areas, 10 caves and 3 springs in the Perhutani area. Morphological changes due to mining can affect the pattern of water distribution, where caves, springs and ponors have a very important role in controlling water supply, the degradation of the amount of water stored in the Watuputih CAT results in changes in the composition of the base flow (diffuse flow) compared to the total flow. Limestone mining will reduce the absorption function and the amount of diffuse water storage, on the contrary will increase conduit flow when it rains. If an area has criteria as karst and CAT areas then it must be a major concern in the sustainability of its ecosystem. Provide protection and stop all activities that can damage geological protected areas that have karst landscapes and water recharge, especially from small scale or massive mining activities. Provides an understanding of karst areas in the perspective of disaster risk reduction. It needs to be developed and informed to various parties across sectors and across administrations so that appropriate policies can be made as an ecological function.

Keywords: Watuputih Groundwater Basin, Water Distribution, Ecosystems, Ecological Function, Protection.

\section{PENDAHULUAN}

Ford dan Williams (1989) mendefinisikan karst sebagai medan dengan kondisi hidrologi yang khas sebagai akibat dari batuan yang mudah larut dan mempunyai porositas sekunder yang berkembang baik. Karst memiliki fungsi strategis sebagai penyimpan cadangan air yang sangat besar di bawah permukaan bentang alam karst dengan karakteristik relief permukaan dan bawah permukaanya yang khas. Bentang alam karst dapat dilihat melalui bukit-bukit kapur kerucut, munculnya mataair-mataair pada rekahan batuan, mengalirnya sungai-sungai bawah tanah dengan lorong gua. Terkadang juga ditemukan lahan kering dibagian permukaanya terutama saat musim kemarau pada bagian - bagian bukit karena sungai sungai yang mengalir di permukaan sangat jarang. Aliran air cenderung masuk ke dalam rekahan batu gamping (limestone) dan melarutkannya. Karst tidak hanya terjadi di daerah berbatuan karbonat, tetapi terjadi juga di batuan lain yang mudah larut dan mempunyai porositas sekunder (kekar dan sesar intensif), seperti batuan gipsum dan batugaram. Namun demikian, karena batuan karbonat mempunyai sebaran yang paling luas, karst yang banyak dijumpai adalah karst yang berkembang di batuan karbonat. Permen ESDM No 17 Tahun 2012 Tentang Penetapan Kawasan Bentang Alam Karst, atau yang lebih dikenal sebagai Kawasan Karst Pegunungan Kendeng Utara. Merupakan bagian dari kelurusan Pegunungan Karst Sukolilo yang membentang dari Grobogan, Pati, Rembang, Blora hingga Tuban yang memanjang dariarah barat - timur. Proses karstifikasi telah terjadi sejak batu gamping sebagai batuan dasarnya tersingkap dan mengalami proses pelarutan. Begitu banyaknya kehadiran gua yang memiliki speleothem-speleothem aktif menunjukkan proses karstifikasi di Pegunungan Kendeng Utara sedang berlangsung. Produk dari dinamika bumi ini yang berlangsung dari masa lalu hingga saat ini telah menghasilkan suatu fenomena alam unik sebagai sebuah bentang alam sekaligus ekosistem kars.

\section{DESKRIPSI LOKASI PENELITIAN}

\section{a. Fisiografi dan Morfologi Pegunungan Watuputih}

Berdasarkan pembagian zona fisiografi daerah CAT Watuputih berada pada Zona Rembang. Zona ini merupakan antiklinorium yang memanjang dengan arah barat-timur, mulai dari sebelah timur Semarang hingga Pulau Madura dan Kangean, memiliki lebar rata-rata $50 \mathrm{~km}$. Merupakan hasil akhir dari gejala tektonik Tersier Akhir (Pringgoprawiro, 1983). Zona ini terdiri atas sikuen mulai dari Eosen hingga 
Pliosen yang berupa sedimen klastik laut dangkal dan karbonat yang luas. Pada zona ini terdapat suatu tinggian (Tinggian Rembang) yang dibatasi oleh sesar mayor berarah ENE-WSW (Smyth, dkk., 2005).

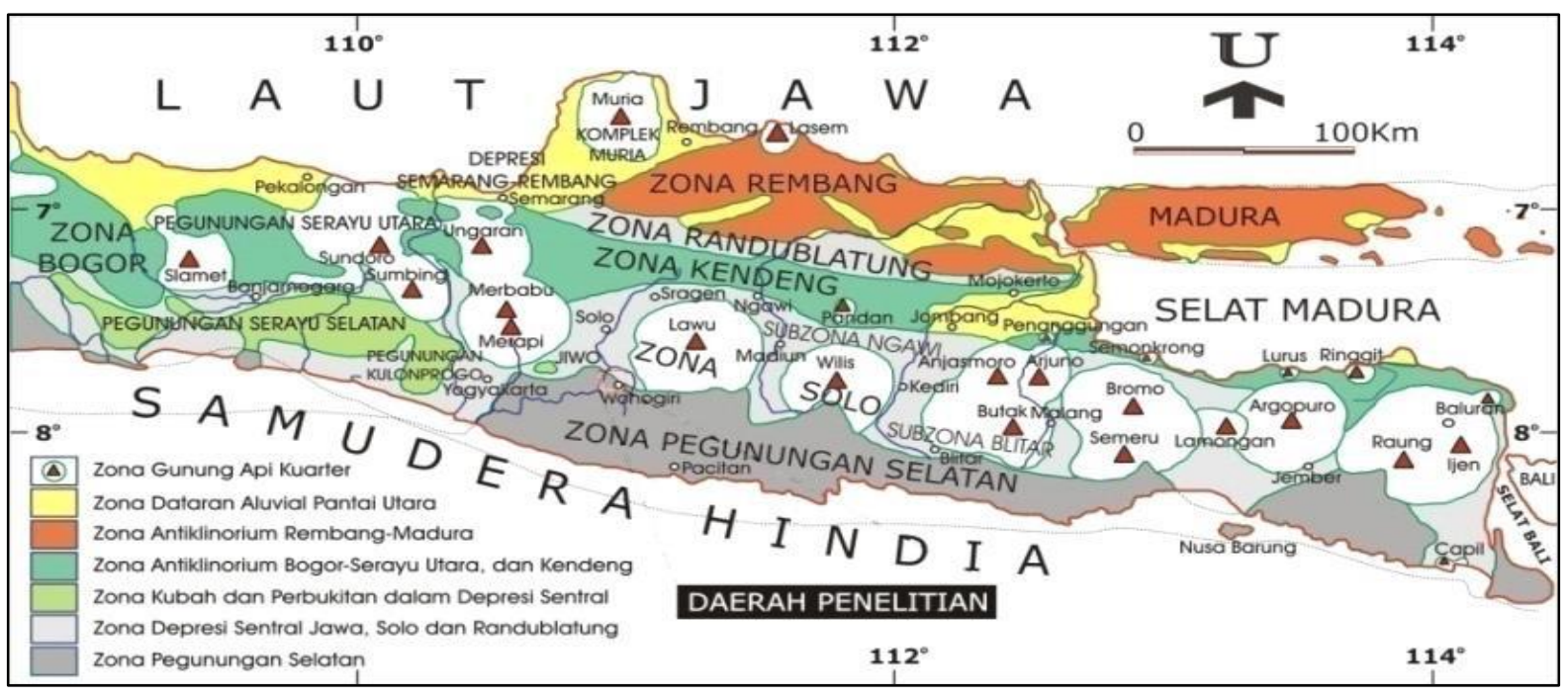

Gambar 1. Fisiografi bagian tengah dan timur Pulau Jawa (Van Bemmelen, 1949).

Berdasarkan Gambar 1. jalur Rembang terdiri dari pegunungan lipatan berbentuk Antiklinorium yang memanjang ke arah Barat - Timur, dari Kota Purwodadi melalui Blora, Jatirogo, Tuban sampai Pulau Madura. Morfologi di daerah tersebut dapat dibagi menjadi 3 satuan, yaitu Satuan Morfologi dataran rendah, perbukitan bergelombang dan Satuan Morfologi perbukitan terjal, dengan punggung perbukitan tersebut umumnya memanjang berarah Barat - Timur dengan ketinggian antara 175 - 455 meter di atas permukaan laut $(\mathrm{m} \mathrm{dpl})$. sehingga pola aliran sungai umumnya hampir sejajar (sub-parallel) dan sebagian berpola mencabang (dendritic). Sungai utama yang melewati daerah CAT Watuputih S. Lusi, S. Tuyuhan dan S. Bengawan Solo.

\section{b. Geologi Pegunungan Watuputih}

Mandala Rembang menurut sistem Tektonik dapat digolongkan kedalam cekungan belakang busur (retro arc back arc) termasuk Zona Fisiografi Rembang (van Bemmelen, 1949). Mandala Rembang tidak mengandung unsur volkanik serta merupakan endapan khas paparan (Pringgoprawiro, 1983). Paparan ini memiliki kemiringan landai ke arah selatan dan diisi oleh endapan relatif tipis. Mandala Rembang mengandung urut-urutan endapan-endapan Kenozoikum yang tebal dan tak terputus hingga Pleistosen.

CAT Watuputih masuk kedalam Formasi Paciran, Formasi Paciran diendapkan tidak selaras di atas Formasi Mundu dan mempunyai hubungan yang menjemari dengan Formasi Lidah. Formasi ini diendapkan pada lingkungan laut dangkal, kemungkinan berupa neritik tengah dengan komposisi batuan batu gamping pejal, batu gamping terumbu dan batu gamping dolomitan (Gambar 2.). 


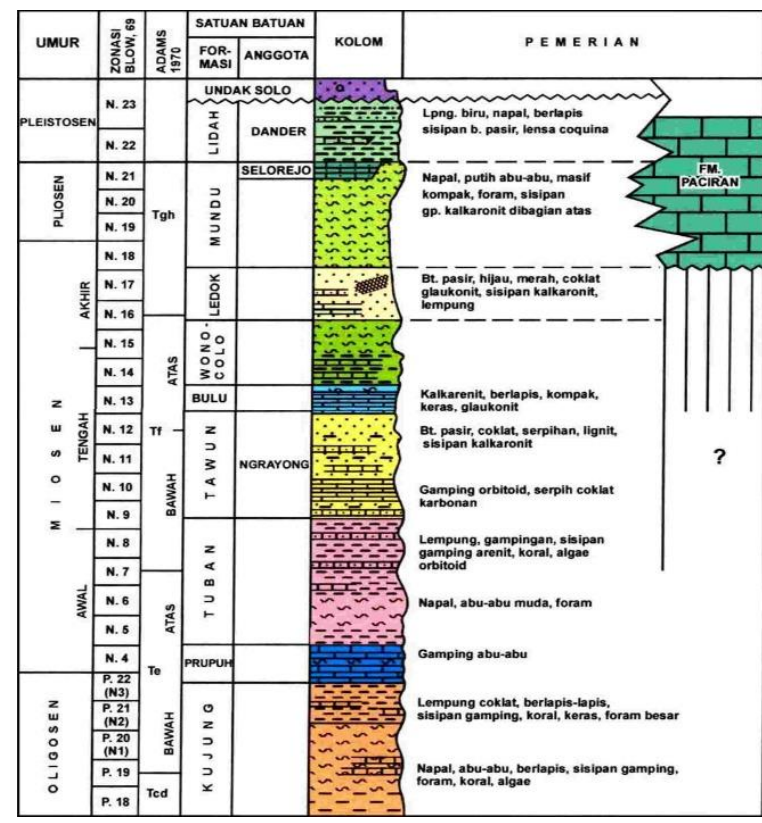

Gambar 2. Kolom Stratigrafi Mandala Rembang (Harsono Pringgoprawiro, 1983).

\section{c. Hidrogeologi dan Speleologi Pegunungan Watuputih}

Akuifer karst dapat digambarkan sebagai sistem yang dibatasi oleh suatu daerah tangkapan air (catchment area) dengan sistem aliran melalui kontrol input dan output (Ford dan Williams, 1989). Batu gamping Formasi paciran membentuk akuifer yang tergantung dari derajat pengkarstsan pada batu gamping itu sendiri yang dipengaruhi oleh zona lemah pada batuan seperti kekar, rekahan dan sesar yang juga mengontrol pola perkembangan lorong - lorong gua yang memiliki kenampakan memanjang, terbentuk dari pelarutan pada bidang perlapisan batuan yang dipengaruhi oleh rekahan - rekahan yang mengikuti pola perlapisaan batuan. Akuifer di CAT Watuputih dikategorikan sebagai akuifer dengan aliran melalui celah, rekahan, dan saluran dengan pola penyebaran setempat umumnya berupa akuifer produktif memiliki muka airtanah dalam serta debit mataair yang cenderung rendah.

Berdasarkan hasil pendataan terdapat 74 gua, 29 mata air, 44 ponor yang berada di daerah Tegaldowo dan Timbrangan serta 47 sumur gali yang berada di sekitar Pegunungan Watuputih. 10 gua dan 3 mata air diantaranya berada di kawasan Perhutani. Mata air Belik Rotan dan Belik Sawahan masuk kedalam area IUP PT Sement Indonesia berada di Kelurahan Kajar Kecamatan Gunem.

Zona jenuh air berada di sekitar sumber Semen dan Mata air Brubuhan berada pada ketinggian 150 mdpl. Data tersebut menguatkan bahwa fungsi Pegunungan Watuputih adalah sebagai kawasan karst, dimana akuifer air masih berjalan dengan sangat baik ditandai dengan mata air yang keluar melalui zona - zona rekahan dan pembentukan sistem sungai bawah permukaan yang ditemukan dalam Gua Temu menunjukkan bahwa Pegunungan Watuputih merupakan 
pegunungan yang mengalami proses karstifikasi aktif sebagai bagian dari Kawasan Karst Pegunungan Kendeng Utara (Gambar 3 dan 4). Perubahan morfologi akibat penambangan dapat mempengaruhi pola distribusi air, dimana gua, mata air dan ponor memiliki peran sangat penting yang mengontrol suplai air, degradasi jumlah air yang tersimpan di dalam CAT Watuputih mengakibatkan perubahan komposisi aliran dasar (diffuse flow) dibanding aliran total. Penambangan bukit gamping akan mengurangi fungsi resapan dan jumlah simpanan air diffuse, sebaliknya akan meningkatkan aliran conduit saat hujan.

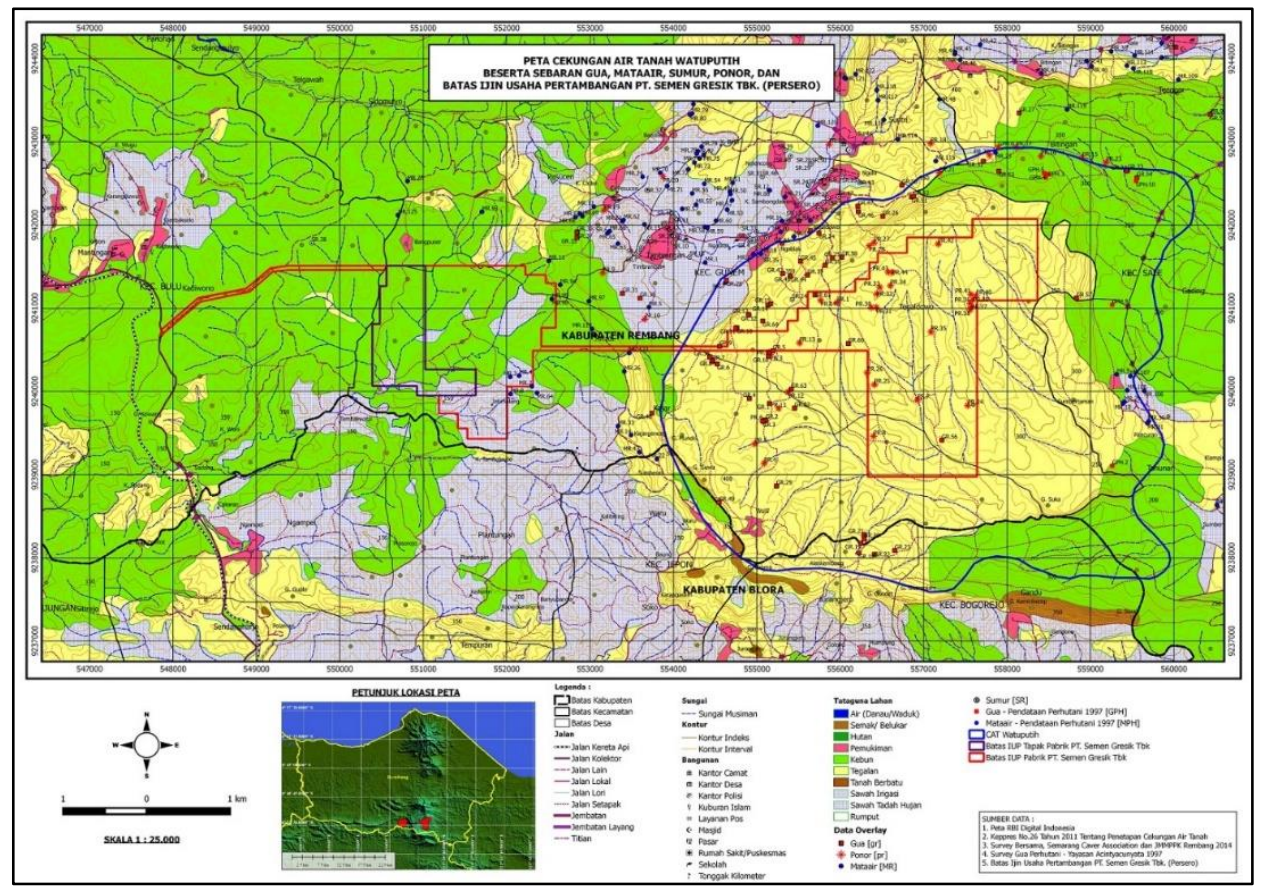

Gambar 3. Peta sebaran Gua, Mata air, Sumur dan Ponor (SCA dan JMPPK Rembang).

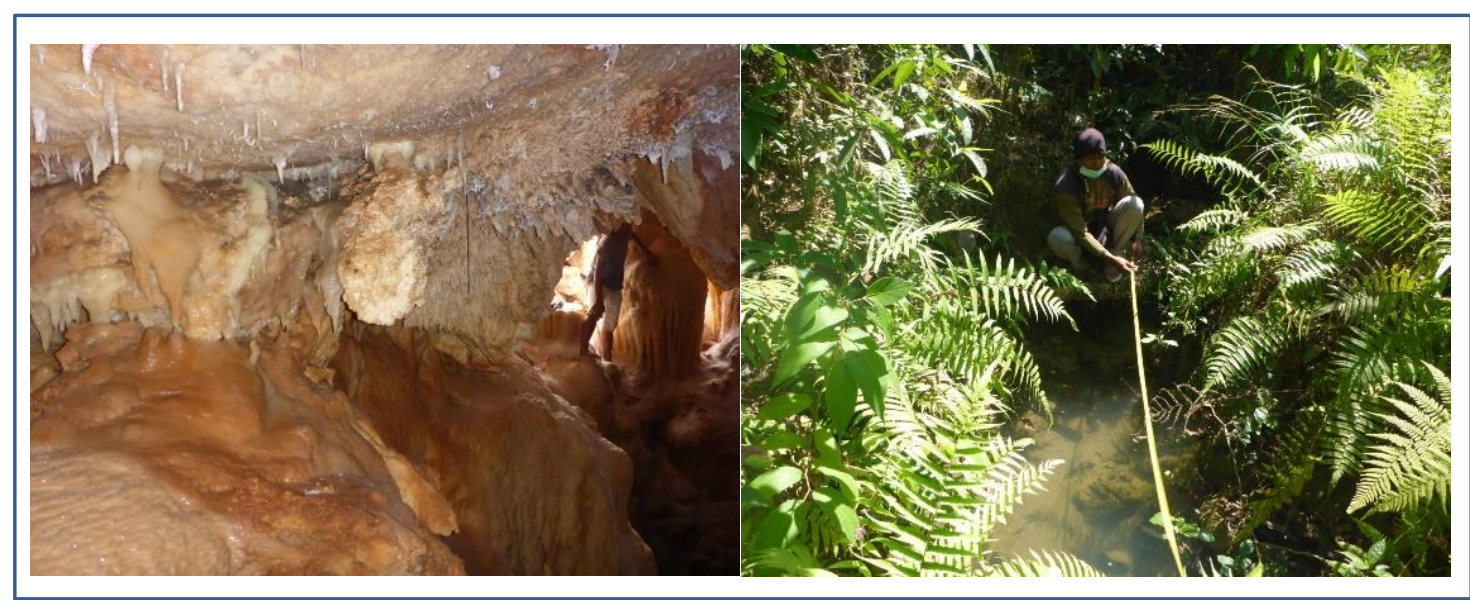

Gambar 4. Foto Gua basah dan Salah Satu Kenampakan Belik/Mata air (SCA dan JMPPK Rembang). 


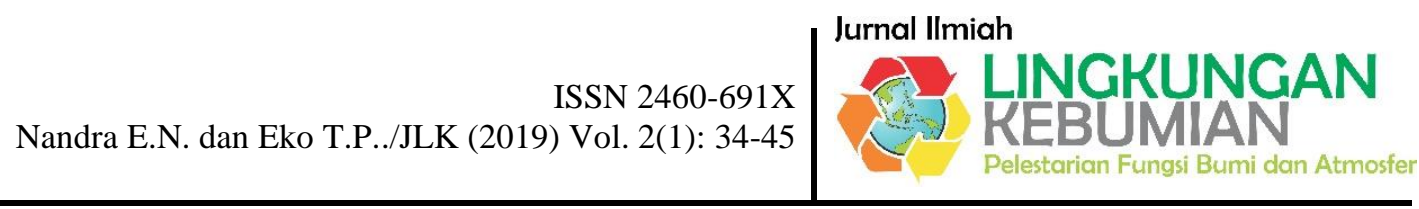

\section{METODE PENELITIAN}

\section{A. Analisis Potensi Risiko Kerusakan Ekosistem Pegunungan Watuputih}

Ekosistem karst merupakan keseluruhan komponen abiotik, biotik, dan budaya yang ada di dalam bentang alam karst Pegunungan Watuputih. Secara biotik ekosistem karst Pegunungan Watuputih merekam evolusi fauna juga perjalanan budaya masyarakat pegunungan Kendeng, secara abiotik berpengaruh pada morfologi, airtanah, sistim speleologi, dan proses yang berkembang di dalamnya.

1. Perubahan morfologi akibat penambangan.

Batu gamping merupakan sumberdaya alam yang melimpah di kawasan karst dan langsung dapat dimanfaatkan dengan melakukan penambangan. Luas batu gamping Formasi Paciran yang membentuk Pegunungan watuputih lebih kurang 3020 Ha. Kawasan CAT Watuputih yang merupakan area imbuhan air sebesar 2555,09681 Ha yang menjadi kawasan resapan air terbesar yang menyuplai sumber mata air yang ada di sekitar kawasan Pegunungan Watuputih. Penambangan dikawasan Pegunungan Watuputih telah dilakukan sejak lama baik dalam sekala kecil (penambangan rakyat) maupun penambangan secara besar.

Berbagi kegiatan penambngan dan rencana pembangunan pabrik semen oleh PT SI dan anak perusahaanya seperti PT SG juga infestor seperti PT SIR, PT RSI, PT GMM, PT BA, PT RBP, PT SAF, PT ICCI yang mencapai luwasan 493 hektare di Tegaldowo, Kecamatan Gunem (BUMN). Kegiatan-kegiatan tersebut secara langsung maupun tidak langsung akan merusak ekosistem gua, sungai bawah tanah dan mata air parenial yang tersebar di wilayah CAT Watuputih. Dari hasil interpretasi citra dan Peta Rupa Bumi Indonesia setidaknya terdapat tiga luwasan daerah tangkapan hilir DAS Sungai Bengawan Solo, Sungai Lusi dan Sungai Tuyuhan merupakan sungai besar yang berhulu di wilayah CAT Watuputih. Daerah Tangkapan Hilir S. Bengawan Solo memiliki luasan $2122 \mathrm{Ha}$, sedangkan daerah tangkapan yang terdampak dengan akan adanya kegiatan penambangan seluas $491.5 \mathrm{Ha}$.

Daerah tangkapan ini secara berurutan akan menyupli air ke S. Mrayun, S. Kowang, S. Kening, dan akan bermuara di S. Bengawan Solo di daerah Bojonegoro. Daerah Tangkapan S. Lusi berada di dalam CAT Watuputih dengan luasan 126.9 Ha tidak terdampak oleh kegiatan penambangan. Daerah yang terdampak berada pada area IUP dan Ijin Pendirian Tapak Pabrik yang berada disebelah barat CAT Watuputih dengan luas terdampak 349.91 Ha. Daerah tangkapan ini secara berututan akan memasok air ke S. Sadang, S. Kedawung, S. Ngampel, dan masuk ke S. Lusi yang akan mengalir melewati Grobogan, Purwodadi. Daerah Tangkapan S. Tuyuhan dengan luas 319 Ha, dan daerah tangkapan yang terdampak dengan akan adanya kegiatan penambangan seluas 69.01 Ha. Daerah tangkapan ini secara berurutan akan menyuplai air ke S. Sambung Dawong, S. Grubugan, S. Kroyo, S.Tuyuhan dan bermuara di laut Jawa didaerah Lasem (Petra Wcana). 


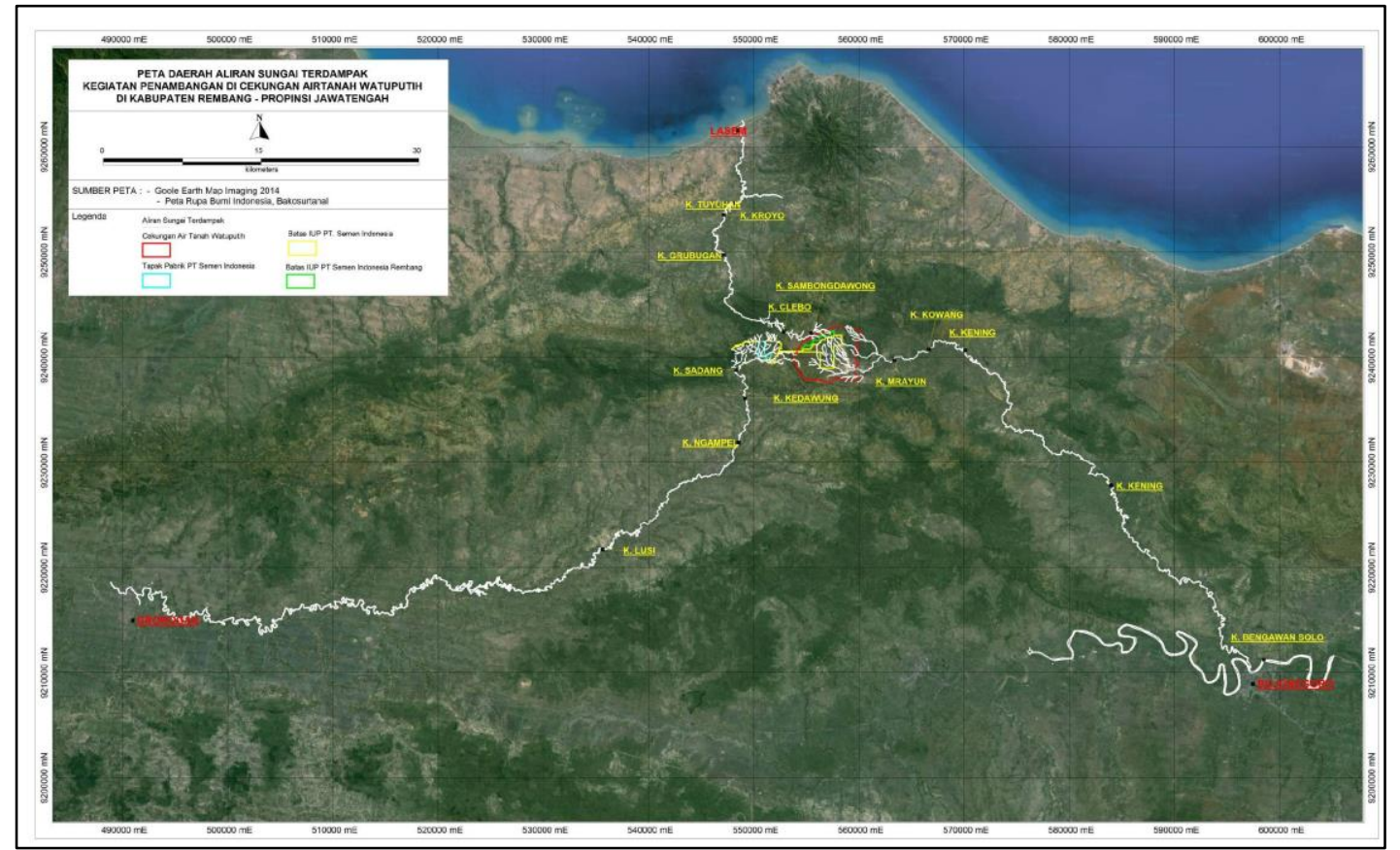

Gambar 5. Peta DAS yang berpotensi terdampak penambangan di CAT Watuputih (Sumber: Peta olahan GIS, 2014)

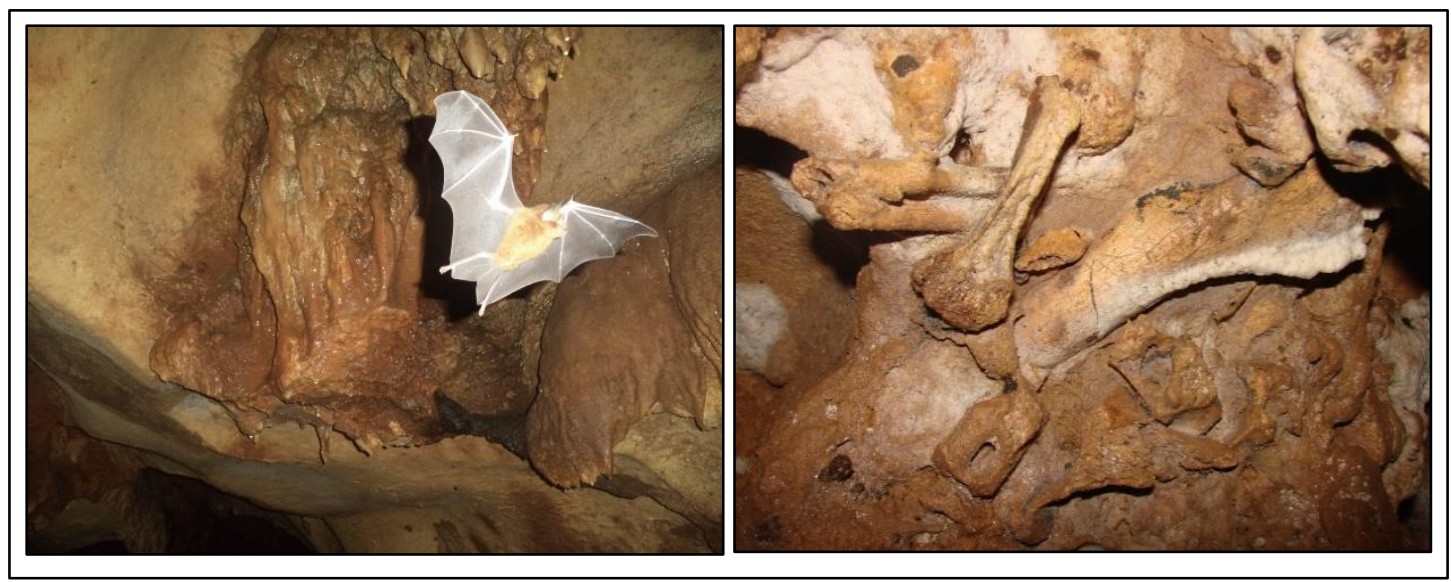

Gambar 6. Foto Biota Gua dan Kenampakan Fosil di Gua Temu (JMPPK Rembang).

2. Penurunan kualitas dan kuantitas air tanah.

Dampak lain dari akibat pertambnagn selain perubahan morfologi pada Pegunungan Wtuputih juga mempengaruhi kulitas dan kuwantitas airtanah. Mudahnya airtanah karst tercemar merupakan konsekwensi perubahan geologi dan geomorfologi yang ada. Hal ini dikarenakan karakter jaringan - jaringan sungai bawah tanah yang langsung terhubung dengan permukaan melalui ponor dan sungai di permukaan sehingga akan berdampak langsung pada airtanah, mataair dan telaga - telaga yang ada.

3. Erosi dan kerusakan speleologi.

Muatan suspensi yang berasal dari erosi tanah permukaan akibat penambngan mengakibatkan rusaknya sistem speleologi yang ada seperti rusaknya ornamen - ornamen gua bahkan dimasa 
mendatang proses - proses pembentukan ornamen gua akan berhenti hal ini akan mengakibatkan berkurangnya suplai air dan jumlah debit yang keluar menjadi mataair. Permasalahan yang lebih khusus dari proses perubahan morfologi akibat penambnagn yaitu rusaknya ekosistem karst secara keseluruhan kondisi ini akan mempengrui bentukan eksokarst maupun endokarst.

4. Budaya masyarakat Pegunungan Watuputih.

Beberapa tradisi masyarakat setempat yang sangat bersahabat dengan alam melarang keras adanya penambangan. Kearifan lokal samin sikep menjaga pegunungan kendeng sangatlah memiliki peran penting mereka meyakini untuk menyukupi kebutuhan hidup mereka sangat bergantung dengan alam, mereka hanya ingin bertani dan berternak. Didalam bertani bukan hanya butuh tanah dan air untuk membuat tanah tersebut menjadi produktif, hal inilah yang menjadikan kearifan lokal sangat peduli lingkungan sekitarnya terbukti pada tahun 2006 dan berhasil menggagalkan rencana PT Semen Gresik untuk membangun pabrik di Kecamatan Sukolilo, Pati, Jawa Tengah. Kegagalan PT Semen Gresik tersebut dikarenakan warga Samin telah memenangkan gugatannya di Pengadilan Tata Usaha Negara (PTUN) hingga Mahkamah Agung. Setelah mundur dari Kecamatan Sukolilo, PT Semen Gresik berpindah ke daerah Kecamatan Gunem, Rembang, PT Semen Indonesia berhasil memasuki daerah Rembang, tepatnya pada tanggal 16 Juni 2014. Potensi pertanian di daerah Pegunungan Watuputih sebenarnya mengalami peningkatan.

Di Kecamatan Gunem jumlah rumahtangga yang berprofesi sebagai petani dari semula 5.810 di tahun 2003 menjadi 5.828 di tahun 2013 atau naik 0,31 persen. (Angka Sementara Hasil Sensus Pertanian Badan Pusat Statistik Rembang 2013). Dari data tersebut dapat dilihat jika wilayahwilayah yang menjadi sasaran perusahaan semen memiliki potensi untuk meningkatkkan hasil pertanian yang ada.

\section{B. Analisis Kebijakan}

Sebagai kawasan karst kawasan ini juga merupakan kawasan imbuhan air terbesar di Kabupaten Rembang yang sering dikenal sebagai Pegunungan Watuputih atau merupakan Kawasan Cekungan Air Tanah (CAT) Watuputih yang tertuang dalam Keputusan Presiden Nomor 26 Tahun 2011 Tentang Penetapan Cekungan Airtanah dalam lampiran poin 124 Cekungan Air Tanah (CAT) Watuputih masuk dalam klasifikasi CAT B yaitu CAT yang berada di lintas kabupaten antara Kabupaten Rembang dan Blora, hal ini menjadikan CAT Watuputih adalah sebagai wilayah konservasi yang harus dilindungi dan dikelola dengan optimal untuk menjaga dari kerusakan wilayah CAT, tertuang dalam pasal 25, Undangundang No 7 tahun 2004 tentang Sumberdaya Air. Kawasan karst adalah kawasan yang harus dilindungi berdasarkan atas klasifikasinya. Secara ekologis, kawasan karst memiliki fungsi yang sangat penting baik sebagai penampung air tanah dalam jumlah besar dan sebagai habitat berbagai jenis flora dan fauna.

CAT Watuputih memilki fungsi epikarst yang jika itu hilang maka akan mengakibatkan hilangnya fungsi resapan air, dimana mata air yang ada di sekitar kawasan karst CAT Watuputih mampu memenuhi kebutuhan 607.198 jiwa di 14 kecamatan, Kabupaten Rembang. Selain itu Cekungan Watuputih adalah kawasan lindung geologi yang seharusnya dilindungi sebagaimana diatur dalam Peraturan Daerah Jawa Tengah Nomor 6 Tahun 2010 Tentang Rencana Tata Ruang Wilayah Provinsi Jawa Tengah Tahun 2010 - 2030. Penetapan kawasan CAT Watuputih sebagai kawasan lindung geologi diperkuat dengan Peraturan Pemerintah No 26 Tahun 2007 tentang RTRW Nasional pasal 53 - 60. CAT Watuputih dalam 
Perda No 14 Tahun 2011 tentang RTRW Kabupaten Rembang masuk ke dalam wilayah kawasan lindung geologi (pasal 19, a), hal ini merujuk pada Perda No 6 Tahun 2010 tentang dimana CAT Watuputih sebagai kawasan resapan air yang menjadi kawasan lindung geologi (pasal 63). Berdasarkan pasal 40 ayat 1, Peraturan Pemerintah No 43 Tahun 2008 tentang Air Tanah mengamanatkan untuk menjaga daya dukung dan fungsi daerah imbuhan air dilakukan dengan cara mempertahankan imbuhan air dan melarang melakukan kegiatan pengeboran, penggalian atau kegiatan lain dalam radius 200 meter dari lokasi kemunculan mata air, ini diperkuat dengan pasal 40 ayat 2 untuk mengamanatkan untuk menjaga daya dukung akuifer dengan mengendalikan kegiatan yang dapat mengganggu sistem akuifer, dalam penjelelasannya disebutkan kegiatan yang dapat mengganggu sistem akuifer adalah antara lain pembuatan terowongan dan penambangan batuan.

Dalam Izin Usaha Pertambangan No 545/0249/2013 yang dikeluarkan oleh pemerintah Kabupaten Rembang di wilayah Desa Tegaldowo, Kecamatan Gunem Kabupaten Rembang kepada PT. Semen Indonesia dimana berdasarkan posisi kordintanya berada di area kawasan Pegunungan Watuputih, yang merupakan sebagai kawasan CAT yang seharusnya dikonservasi dan dilindungi. Pasal 1 ayat 1 UU no 24 tahun 2007, peristiwa atau rangkaian pristiwa yang mengancam dan mengganggu kehidupan dan penghidupan masyarakat yang disebabkan, baik oleh faktor alam dan atau faktor nonalam maupun faktor manusia sehingga mengakibatkan timbulnya korban jiwa manusia, kerusakan lingkungan, kerugian harta benda dan dampak psikologis.Dalam konteks pendekatan kebencanaan hal ini dapat diaplikasikan sebagai risiko bencana karena kontrol terhadap penguwasaan dan pengelolaan semberdaya alam yang secara tiba - tiba dan berangsur berpotensi sebagai sember bahaya bencana yang berpengaruh pada penataan ruang dan pengelolaan lingkungan hidup (pasal 35, b, d).

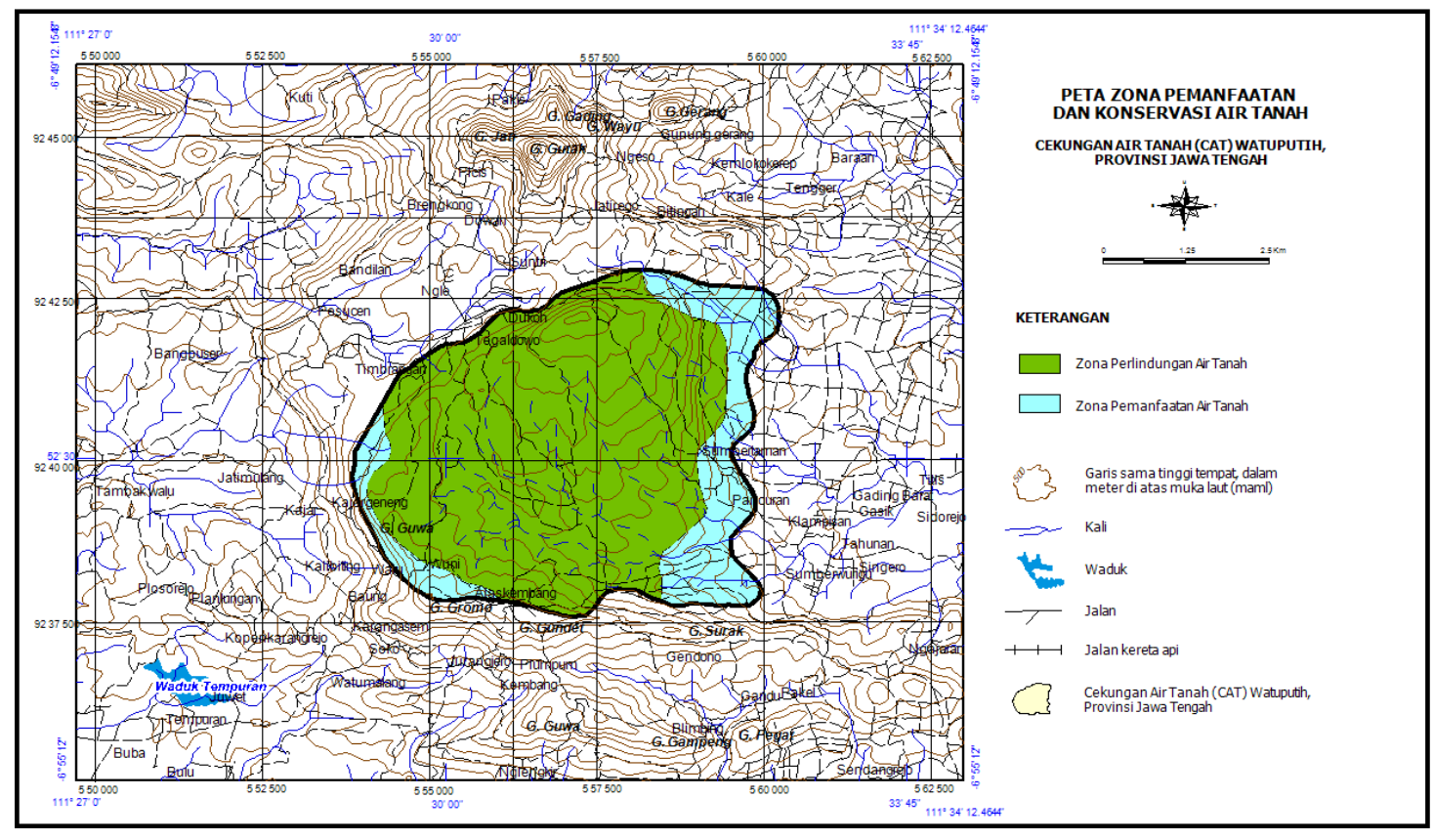

Gambar 7. Peta zona pemanfaatan dan konservasi air (Badan Geologi). 


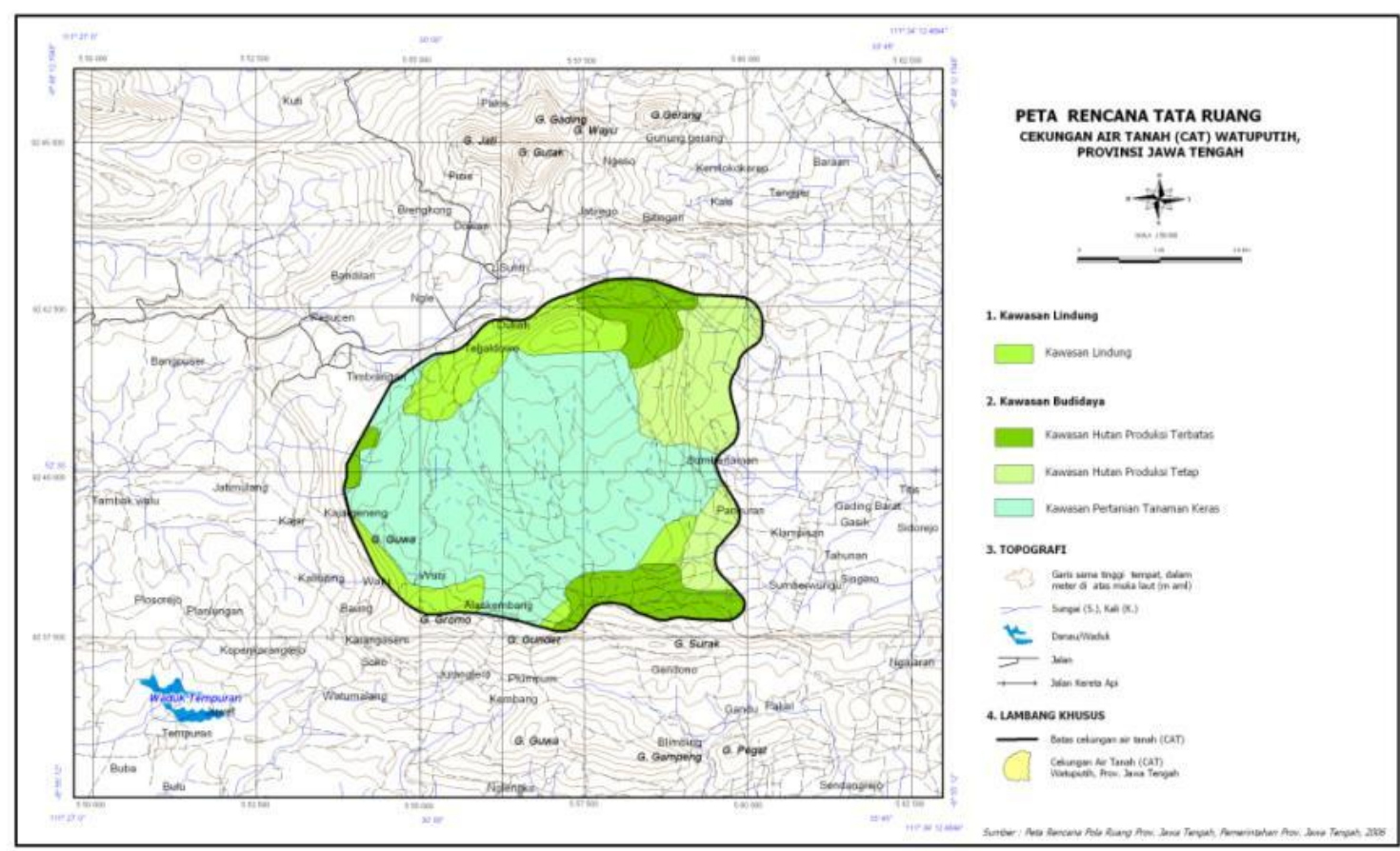

Gambar 8. Peta rencana tata ruang CAT Watuputih (Badan Geologi).

\section{KESIMPULAN}

1. Permen ESDM No 17 Tahun 2012 Tentang Penetapan Kawasan Bentang Alam Karst, atau yang lebih dikenal sebagai Kawasan Karst Pegunungan Kendeng Utara. Merupakan bagian dari kelurusan Pegunungan Karst Sukolilo yang membentang dari Grobogan, Pati, Rembang

2. CAT Watuputih masuk kedalam Formasi Paciran, Formasi ini diendapkan pada lingkungan laut dangkal, kemungkinan berupa neritik tengah dengan komposisi batuan batu gamping pejal, batu gamping terumbu dan batu gamping dolomitan

3. Akuifer di CAT Watuputih dikategorikan sebagai akuifer dengan aliran melalui celah, rekahan, dan saluran dengan pola penyebaran setempat umumnya berupa akuifer produktif memiliki muka airtanah dalam serta debit mataair yang cenderung rendah

4. Ekosistem karst merupakan keseluruhan komponen abiotik, biotik, dan budaya yang ada di dalam bentang alam karst Pegunungan Watuputih. Secara biotik ekosistem karst Pegunungan Watuputih merekam evolusi fauna juga perjalanan budaya masyarakat pegunungan Kendeng, secara abiotik berpengaruh pada morfologi, airtanah, sistim speleologi, dan proses yang berkembang di dalamnya.

5. Berbagi kegiatan penambngan dan rencana pembangunan pabrik semen oleh PT SI dan anak perusahaanya seperti PT SG juga infestor seperti PT SIR, PT RSI, PT GMM, PT BA, PT RBP, PT SAF, PT ICCI yang mencapai luwasan 493 hektare di Tegaldowo, Kecamatan Gunem.

6. Dari hasil interpretasi citra dan Peta Rupa Bumi Indonesia setidaknya terdapat tiga luwasan daerah tangkapan hilir DAS Sungai Bengawan Solo, Sungai Lusi dan Sungai Tuyuhan merupakan sungai besar yang berhulu di wilayah CAT Watuputih.

7. Muatan suspensi yang berasal dari erosi tanah permukaan akibat penambngan mengakibatkan rusaknya sistem speleologi yang ada seperti rusaknya ornamen - ornamen gua bahkan dimasa 
mendatang proses - proses pembentukan ornamen gua akan berhenti hal ini akan mengakibatkan berkurangnya suplai air dan jumlah debit yang keluar menjadi mataair

8. Kearifan lokal samin sikep menjaga pegunungan kendeng sangatlah memiliki peran penting mereka meyakini untuk menyukupi kebutuhan hidup mereka sangat bergantung dengan alam, mereka hanya ingin bertani dan berternak. Didalam bertani bukan hanya butuh tanah dan air untuk membuat tanah tersebut menjadi produktif, hal inilah yang menjadikan kearifan lokal sangat peduli lingkungan.

\section{REKOMENDASI}

1. Apabila sebuah kawasan memiliki kriteria sebagai kawasan karst dan CAT maka harus menjadi perhatian utama dalam keberlanjutan ekosistemnya.

2. Meninjau tumpang tindihnya peraturan dan kepentingan pemerintah atas ijin pertambnagn yang diperoleh PT SI terkait status CAT Watuputih adalah CAT B dan kawasan lindung geologi.

3. Memberikan perlindungan dan menghentikan semua aktifitas yang dapat merusak kawasan lindung geologi yang memiliki bentang alam karst dan imbuhan air, terutama dari kegiatan tambang sekala kecil maupun secara masiff.

4. Memberi pemahaman tentang kawasan karst dalam perspektif pengurangan risiko bencana. Perlu dikembangkan dan diinformasikan ke berbagai pihak lintas sektor dan lintas administrasi sehingga dapat dilakukan kebijakan yang tepat sebagai fungsi ekologis.

5. Memetakan dan mengkaji lagi secara lebih detil dan terstruktur sistem hidrologi bawah permukaan yang ada, dengan perbandingan pada saat musim panas dan musim hujan.

6. Melakukan pemetaan gua secara detil dan melakukan pendataan biota yang ada di dalamnya.

7. Memperkuat dan memperluas Jaringan Masyarakat Peduli Pegunungan Kendeng.

\section{DAFTAR PUSTAKA}

Adji, T,N. (2013). Kondisi Tangkapan Sungai Bawah Tanah Karst Gunungsewu dan Kemungkinan Dapak Lingkungan Terhadap Sumberdaya Air (Hidrologi) Karena Aktivitas Manusia. Paper diakses dari http://tjahyo-adji.staff.ugm.ac.id/ancaman_karst_aquifer.pdf.

Anonim. (2012). Analisa Dampak Lingkungan (ANDAL) PT. Semen Indonesia, Kabupaten Rembang, jawa Tengah.

Anonim. (2004). Undang-undang Nomor 7 Tahun 2004 Tentang Sumberdaya Air.

Anonim, (2008). Peraturan Pemerintah Nomor 26 Tahun 2008 Tentang Rencana Tata Ruang Tata Wilayah Nasional.

Anonim, (2010). Peraturan Daerah Nomor 6 Tahun 2010 tentang Rencana Tata Ruang Tata Wilayah Propinsi Jawa Tengah.

Anonim, (2011). Peraturan Daerah Nomor 14 Tahun 2011 tentang Rencana Tata Ruang Tata Wilayah Kabupaten Rembang.

Anonim, (2011). Keputusan Presiden Nomor 26 Tahun 2011 Tentang Penetapan Cekungan Air Tanah. 


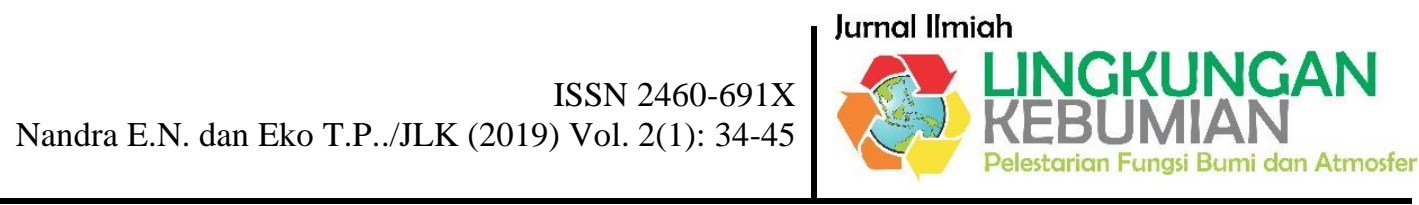

Anonim, (2012). Peraturan Mentri Energi dan Sumberdaya Mineral Nomor 17 Tahun 2012 Tentang Penetapan Kawasan Bentang Alam Karst.

Anonim, (2013). Surat Izin Wilayah Usaha Pertambangan No 545/0249/2013. PT Semen Indonesia, Kabupaten Rembang.

Bogli, A. (1980), Karst Hydrology and Physical Speleology, Springer Verlag, 284 hal.

Bemmelen, R.W.V. (1970). The Geology of Indonesia, Vol IA General Geology of Indonesia and Adjacent Archipelagoes, Second Edition, Martinus Nilhoff, The Haque, Netherlands.

Esteban, M. (1996). Karst System from Prospect to Reservoir, Carbonate International Ltd., 168 hal.

Ford D.C. dan Williams P.W. (1989). Karst Geomorphology and Hydrology, Chapman and Hall, London.

Kurniawan, R., Eriyatno, Sardiadiaja, R., dan Zain. (2009). Valuasi Ekonomi Jasa Lingkungan Kawasan Karst Maros-Pungkep. Gunung Sewu, Indonesian Karst and Cave Journal, Volume 5(1).

Klimchouk, A., (1997). The nature and principal characteristics of epikarst. In: P.-Y. Jeannin (Editor), $12^{\text {th }}$ International Congress of Speleology, La Chaux-de-Fonds, pp. 306.

Kusumayudha, S.B. (2004). Mengenal Hidrogeologi Karst, Pusat Studi Karst LPPM UPN "Veteran" Yogyakarta, 137 hal.

Kusumayudha, S.B. (2013). Kars : Gua Batu gamping, Sungai Bawah Tanah, dan Mata Air.

Van Bemmelen, R.W. (1949). The Geology of Indonesia, Vol. IA, The Hague Martinus Nijhoff, Netherlands, 732 hal.

Van Zuidam, R. A.(1983). Guide to Geomorphologic Aerial Photographic Interpretation and Mapping, section of Geology and Geomorphology, ITC, Enschede, the Netherlands, 325 p.

Wacana, Rodialfalah, dan Chandra. (2008). Kajian Potensi Kawasan Karst Kendeng Utara Kabupaten Grobogan dan Kabupaten Pati. Paper Ilmiah ISKF \#1, UGM Yogyakarta, 2010. 